Popov 0., Serdukov K.

\title{
ESTIMATION OF STRUCTURAL ORGANIZATION OF CORPORATE RELATIONS AT FORMING OF CORPORATION DEVELOPMENT STRATEGY
}

Розглянуто організаційні аспекти корпоративних відносин у акціонерному товаристві при формуванні стратегії розвитку корпорації. Запропоновано методичний підхід до оцінки структурної організації корпоративних відносин та розподілу корпоративного контролю у акціонерному товаристві. Розглянуто мотиваційне забезпечення подолання опору організаційним змінам в процесі реалізації стратегії розвитку акиіонерного товариства.

Ключові слова: корпоративні відносини, акціонерне товариство, стратегія розвитку, корпоративний контроль, корпоративне управління.

\section{Introduction}

As a result of the unfolding of the denationalization process in the national economy of Ukraine, a mixed (hybrid) type corporate governance system has developed, within which currently there is a manifestation of the system of outsiders (a very high level of fragmentation of shares in joint-stock companies (JSC), a huge number of owners of small packages of shares), insiders (three-level structural structure of the supreme bodies of corporate governance, the spread of the trend of concentration of the shareholder (the large-scale presence of the state in corporate relations, the spread of the use of complex forms of economic integration of a representative corporate type, such as cross and reciprocal ownership, personal unions, etc.). In the course of the emergence, functioning and development of developed hybrid of the corporate governance system (CGS) in the sphere of corporate relations, numerous contradictions occurred due to a wide range of causes and circumstances, the most important of which include the following: revolutionary (through artificially accelerated corporatization of state enterprises). The nature of the origin of corporate relations; lack of a proper institutional (organizational and regulatory framework) for the good perception of the ideology and practice of corporatism by potential members of corporation; unfavorable general economic conditions (the growth of crisis phenomena associated with the transformation of the economic mechanism) for the perception of complex forms of business organization,

So, one of the mandatory requirements to overcome the contradictions associated with the unnatural genesis of creation and the development of the national model of corporate governance should be considered the solution of the task of improving the organization of corporate relations in accordance with the needs to ensure the sustainable development of domestic joint-stock companies. The solution of this complex problem is considerably hampered by the obvious requirements of simultaneously taking into account the following main aspects of it. First, the urgent need for rapid changes in the national corporate governance system should promote the further dissemination of the corporatism principles in relations between economic agents participating in corporate relations (CR), thus creating the prerequisites for the further formation of an appropriate basis for CGS transformation. Secondly, because of the existence and gradual aggravation of internal contradictions associated with the existing imbalance in the structural construction of corporate relations, both on the institutional and within the CGS itself, the inevitability of deepening is determined by the mixed nature of its construction (the artificiality of reporting individual components) and which can significantly impede the implementation of relevant positive changes. Thirdly, the need to overcome subjective resistance and resistance to any attempts to modernize the corporate sector and implement the strategy of sustainable development of domestic corporations by some influential social groups whose interests are in line with the current state of unsettled corporate relations, etc.

\section{The object of research and its technological audit}

Successful transformation of relations and forms of ownership in Ukraine has become only one of the prerequisites for fulfilling the main task of denationalization process, which consists in the formation of an optimal ownership structure for privatized enterprises that would enhance the efficiency of economic activity, intensify investment processes of renewal of the production base, improve the welfare of society, etc. On the contrary, the model of the organization of corporate relations, formed in Ukraine during mass privatization, has become a source of numerous obstacles to the sustainable development of domestic corporations and the establishment of effective mutually beneficial cooperation between the CR participants.

So, after the mass privatization process (2000) was completed, there were 35.26 thousand joint-stock companies 
in Ukraine, incl. 11.85 thousand of Open Joint Stock Companies (33.6 \% of the total number) and 23.41 thousand of Closed Joint Stock Companies (76.4\%). So, at that time only a third of joint-stock companies (open type) had the potential to raise funds on the open market. However, already from the following year, 2001, the number of shareholders of domestic JSC gradually began to decline, and in 2008, registrars registered only 11.860 thousand of personal accounts of shareholders. Thus, the completion of mass privatization was marked by the activation of the share capital concentration, carried out by the owners of large blocks of shares through the purchase of shares of corporate rights in minority shareholders. In the future, the tendency of accumulation of blocks of shares by legal entities (LE) has only deepened. Thus, the number of shareholders-LE during 2004-2008 decreased very slightly, which became especially noticeable against the background of a nearly twofold decrease in the number of private shareholders (from 64.0 thousand to 59.0 thousand people). In this period, the nominal value of shares that belonged to shareholders-LE, grew 1.7 times for residents (from 66.73 billion UAH to 113.93 billion UAH), for nonresidents - by 1.3 times (from 5.64 billion UAH up to 7.36 billion UAH). At the same time, the nominal value of corporate rights, owned by individuals, increased by only $22 \%$ (from 12.5 billion UAH to 15.27 billion UAH, respectively), which indicates a reduction in the role and place of individuals in corporate relations. The narrowing of the circle of shareholders of domestic corporations with the growth of the nominal value of corporate rights that belong to them is explained not only by the activation of the accumulation of capital assets, but also by the decrease in the number of joint-stock companies. So, during the period 2006-2009, the number of joint-stock companies in Ukraine decreased by $9.65 \%$ (from 33976 units to 30696 units), including: OJSC - by $12.99 \%$ (from 11345 units to 10406 units), CJSC - by $7.92 \%$ (from 21948 units to 20209 units). In the future, the negative tendency to restrict the productive use of the joint-stock form of business organization in Ukraine only deepened: in 2015 the number of operating JSCs (public and private type) was 15.9 thousand units, in 2016 15.6 thousand units, in 2017 - 15.2 thousand units.

\section{The aim and objectives of research}

The aim of research is development of theoretical and methodological provisions for evaluating the structural organization of corporate relations in the formation of the company's development strategy.

To achieve this aim, the following tasks are defined:

1. Development of methodological approach to determining the nature of the representation of shareholders in the various governing bodies of the joint-stock company, different in their influence when forming the corporate development strategy.

2. Development of methodological provisions for integrated assessment of corporate governance quality based on the evaluation of the structural organization of corporate relations in joint-stock companies.

3. Generalization of the forms, reasons and ways to overcome the resistance to organizational changes in the process of implementing the JSC development strategy.

\section{Research of existing solutions of the problem}

Corporate relations and corporate organization in modern scientific research are considered primarily as a form of realization of corporatism ideology, according to the provisions of which the joint activity of corporations (participants in corporate relations) has to unfold to achieve common goals and interests, the source of satisfaction of which is corporate cooperation within certain corporate organizations. However, the nature and patterns of development of this kind of cooperation, its organizational aspects and structural structure within the framework of existing jointstock companies remains the subject of scientific discussions.

Thus, in [1-4], the structural structure of a corporate association is defined by a blurred and weakly formalized character, that is, no special organizational or regulatory (except for general acts) restrictions are established for the corporation's activity, and the corporation acts as a form of consolidation of interests of social groups stratified primarily on the basis of professional or class characteristics. In studies $[5,6]$, on the contrary, attention is focused on purely economic aspects of corporate relations. The corporation at the same time is considered to be the organizational form of the process of economic integration, to which both private individuals (acting as carriers of private interests) and enterprise-organizations (personifying a certain kind of collective interests) can participate. On the other hand, the authors of [7-9] insist on the approach according to which the corporation is considered as a socio-economic organization formed on the basis of the association of property of shareholders solely to achieve their goals. The rest of the other interest groups are excluded from the corporate cooperation process within the corporation - hence, it is considered that the content of the corporate organization is provided only by the so-called Internal (joint-stock) corporate relations between owners-shareholders. The corporation can also act as a separate party in relations with the owners, but such interaction will be of a two-sided nature: firstly, shareholders can use their powers to participate in the formation of collective will (to realize a share of corporate control), embodied in the actions of the corporation, and secondly, they themselves will have to face the embodiment of this freedom. The authors of [10-12] adhere to a different approach, according to which the corporation is considered a form of legal implementation and organizational recovery of a wide range of mutual relations of participants in corporate cooperation. The peculiarity of corporate regulation of this kind of relations consists in the mandatory nature of the formation of a special third person - the corporation itself, on the basis of autonomy and separation - the personification of the general will of participants in corporate cooperation.

However, the presence of objective contradictions between the goals, interests and the corresponding models of behavior of various groups of corporate bodies naturally causes the possibility of the emergence of numerous contradictions and corporate conflicts both between such groups and within them. The most significant factors of the influence of participants in corporate relations are, first of all, clear and indisputable property rights, the availability of special knowledge and experience, free financial resources, legal support, possibility of applying administrative interference of state bodies, etc. Mutually 
beneficial balancing of the aspirations of corporations in the joint-stock company is an indispensable condition for stable economic development.

\section{Methods of research}

To achieve the aim and solve the tasks set, the following research methods are used: system analysis - to study the structure of ownership and the specifics of the organization of corporate relations in joint-stock companies; formalization - to develop a methodological approach to evaluating the structural organization of corporate relations in a joint-stock company.

\section{Research results}

One of the main areas of the dynamic aspect of the organization of corporate relations and the functioning of the corporate governance mechanism is the emergence of competition situations for corporate control in formation of the system of higher governance bodies of joint-stock companies. The legal basis for formation of this system in the joint-stock company is based on the following principles: delineation of competence between governance bodies of joint-stock companies; centralization of the functions of management and control over the activities of the company ensuring effective control over the activities of the board by the supervisory board and the accountability of the supervisory board to the general meeting of shareholders; «conquering the minority of the majority» when making decisions by shareholders (through the collegial nature of the construction of all the governance bodies of the jointstock company provided that the mechanisms for protecting the interests of the minority are applied simultaneously). For the insider system of corporate governance, which arose at this time in Ukraine, the governance structure of joint-stock companies consists of three levels. The highest level is the general meeting of shareholders, below is the shareholders' council (supervisory board) and the audit commission, and even lower - the executive body of the company. The procedure for the formation of the governance bodies of a joint-stock company is determined by the legislation of Ukraine, the charter and other internal regulatory documents of the company.

Thus, it is through the organization of the activities of the supreme governance bodies of the joint-stock company that control over the activities of the corporation takes place. So, it is expedient to develop the system of corporate control indicators in a joint-stock company based on the definition of the representation nature of shareholders in various top governance bodies of the JSC as influential.

The weight coefficient of influence of the supreme governance body of the joint-stock company when making managerial decisions:

$$
K j^{v}=\frac{\sum_{i=1}^{n} S_{i}{ }^{j}}{n},
$$

where $K j^{v}$ - the weight coefficient of influence of the $j$-th supreme governance body of the JSC; $n$ - the number of governance decisions of a general and specific nature, whose powers in the sphere of adoption are taken into account when establishing the influence of the $j$-th supreme governance body of the JSC, units; $\mathrm{Si}$ - governance decisions of a general and specific nature, the authority for the adoption of which must be attributed to the competence of a certain supreme governance body of joint-stock companies $(i=1 \ldots n)$, units; $S_{i}{ }^{j}$ - ownership indicator of the $S_{I^{-}}$-th governance decision of a general and specific nature in the sphere of authority (competence) of the $j$-th JSC supreme governance body:

$$
S_{i}{ }^{j}=\frac{1}{e},
$$

where $e$ - the number of supreme governance bodies, whose powers include the adoption of governance decisions $(m=1 \ldots 3)$, units.

The indicator of duplication (coincidence) of the powers of the supreme governance bodies of the JSC:

$$
K d=\frac{b+d}{m},
$$

where $b$ - the number of governance decisions of a general nature, authority in the sphere of adoption is assigned to the competence of the two supreme governance bodies of joint-stock companies, units; $d$ - the number of governance decisions of a general nature, authority in the sphere of adoption is referred to the competence of the three supreme governance bodies of the JSC, units; $m$ - the number of governance decisions of a general nature, the authority in the sphere of adoption is taken into account when establishing the duplication of competencies of the supreme governance bodies of joint-stock companies, units.

The presented scheme for assessing the effectiveness of corporate control includes five main areas that characterize the structural, regulatory, procedural, effective, communicative aspects of corporate governance.

Representation indicator of shareholders in the supreme governance bodies of the joint-stock company:

$$
K_{p}{ }^{2}=\frac{\sum_{j=1}^{q} \frac{h_{j}^{z}}{t_{j}}+\frac{D^{z}}{100}}{q+1},
$$

where $K_{p}{ }^{z}$ - representation indicator of the $z$-th group of shareholders in the supreme governance bodies of the jointstock company; $h_{j}^{z}$ - the number of representatives of the $z$-th group of shareholders in the $j$-th supreme governance body of the joint-stock company, persons; $t_{j}$ - total number of members of $j$-th supreme governance body of the jointstock company, persons; $q$ - the number of governance bodies of the joint-stock company (supervisory board and board of JSCs), whose members are shareholders or representatives of shareholders (in the general case $q=2$ ); $D^{z}$ - shares belonging to the $z$-th group of shareholders in the authorized capital of the joint-stock company, \%.

The influence indicator of shareholders in the exercise of authority to participate in the work of the supreme governance bodies of the joint-stock company:

$$
K_{w}{ }^{z}=\frac{\sum_{j=1}^{q}\left(\frac{h_{j}{ }^{z}}{t_{j}} \times K_{j}^{v}\right)+\frac{D^{z}}{\sum_{u=1}^{y} D_{u}{ }^{z}} \times K_{d}^{v}}{\sum_{j=1}^{q+1} K_{j}^{v}}
$$


at

$$
\sum_{u=1}^{y} D_{u}{ }^{2}>\hat{D}^{\prime}
$$

where $K_{w}{ }^{2}$ - influence indicator of the $z$-th group of shareholders in the $j$-th supreme governance body of the jointstock company $(j=1 \ldots q) ; K_{d}^{v}$ - weight coefficient of influence of the shareholders' meeting of JSCs; $u$ - the number of $z$-groups of shareholders who took part (registered for participation) in the general meeting $(u=1 \ldots y) ; \hat{D}^{\prime}-$ the maximum value of the number of shares, the registration of owners (or representatives of owners) who, for participation in the shareholders' meeting, determines the existence of a quorum necessary for the recognition of this meeting as the occurred, \%.

Completeness indicator of normative regulation of corporate relations in a joint-stock company:

$$
K^{n}=\frac{\sum_{j=1}^{r}\left(\frac{\sum_{x=1}^{g} F_{x}^{j}}{g} \times K j^{v}\right)}{r \times \sum_{j=1}^{r} K j^{v}},
$$

where $K^{n}$ - completeness indicator of normative regulation of corporate relations in the joint-stock company; $x$ - the total number of internal corporate regulations (the existence of relevant provisions), which should regulate the activities of the $j$-th supreme governance body of the JSC, units, $(X=1 \ldots g)$; $F_{x}{ }^{j}$ - the number of normative documents of intracorporate nature (the existence of relevant provisions), which actually regulate the activities of the $j$-th supreme governance body of the JSC, units, $(I=1 \ldots r)$, units; $r$ - the number of governance bodies of the joint-stock company, the functioning of which is subject to regulation (in general, $q=3$ ).

Information openness indicator of the joint-stock company:

$$
K^{i}=\frac{\sum_{s=1}^{c} I_{c}}{c},
$$

where $K^{i}$ - information openness indicator of the joint-stock company; $s$ - sources of information on the state of corporate relations in the joint-stock company $(s=1 \ldots s) ; I_{c}$ - openness indicator of the $s$-th source of information on the state of corporate relations in the joint - stock company.

External openness indicator (attraction of external counterparties to servicing corporate relations) of the joint-stock company:

$$
K^{\alpha}=\frac{\sum_{\beta=1}^{\delta} L_{\beta}}{\delta},
$$

where $K^{\alpha}$ - external openness indicator (attraction of external counterparties to servicing corporate relations) of the joint-stock company; $\beta$ - operations for servicing corporate relations, to the implementation of which external contractors may be attracted $(\beta=1 \ldots \delta) ; L_{\beta}$ - openness indicator of the $\beta$-th operation to service corporate relations, to which external contractors were involved.

The resulted methodical approach to calculation of system of indicators which reflect a condition of distribu- tion of the corporate governance in joint-stock company in the further will be used for definition of an indicator of the structural organization of corporate relations in joint-stock company.

Securing the rights and interests of shareholders, achieving an acceptable level of efficiency in the use of share capital primarily depends on the perfection and effectiveness of joint-control procedures, the core of which is the assessment of the quality and effectiveness of corporate governance.

The evaluation of corporate governance in the JSC is primarily to characterize the management situation around the governance object (CR) from the following positions: goals (normative indicators of the desired or ideal state) of the corporation (with reference to specific priorities for the participation of certain persons in CR), activity and initiative in CGs, etc.) the ability (potential) of the corporation, if possible, to achieve these goals; degree of use of the CG potential; contribution (role and importance) of corporate governance in achieving the set goals based on the use of the potential of corporate governance; perfection degree of corporate relations, that is, the level of protection and enforcement of legitimate rights and interests of all CR participants in accordance with their contribution to corporate cooperation.

From this point of view, it seems advisable to distinguish between the procedures for researching the level of corporate governance in a joint-stock company into two blocks: determining the CG effectiveness and assessing the CG quality.

The development of the static component of corporate governance (organizational, economic and regulatory support of CR) is proposed to be implemented on the basis of a comprehensive assessment of the structural organization of CR in JSC. This assessment provides for the use of a general indicator, the peculiarity of which is to take into account the concentration of ownership of corporate rights (CR), the influence of the supreme governance bodies (SGB) of JSC when making managerial decisions, representation of shareholders in SGB, completeness of normative regulation of corporate relations in JSC, information and external openness of joint-stock company that will allow to form a complex assessment of possible variants of distribution of the corporate control in joint-stock company and division of powers on decision-making of the general administrative decisions between the supreme governance bodies:

$$
K s=\frac{S_{R}}{S p}=\frac{\sum_{i=1}^{e}\left(\frac{1}{2} \times\left(K_{i} \times K_{i+1}\right)\right)}{\pi \times l^{2}},
$$

where $K s$ - generalized indicator of the structural organization of corporate relations in a joint-stock company; $S_{R}-$ the area of the radar (polygon) formed by positioning the $K_{i}$-th values of the valuation indicators on the assessment plane of the structural organization of corporate relations in the joint-stock company; $S p$ - the plane of the assessment plane of the structural organization of corporate relations in a joint-stock company; $K_{i}-i$-th assessment indicator of the structural organization of corporate relations in the jointstock company; $i$ - the number of indicators for evaluating the structural organization of corporate relations in a joint-stock company (in the general case, $i=8) ; \pi-$ a constant $(\pi=3.14$ ); $l$ - the radius of the assessment plane of the structural organization of corporate relations in a joint-stock company $(l=1)$. 
The highest level of structural organization of corporate relations peculiar to joint-stock companies with a significant and high concentration of ownership of corporate rights, for which, however, there remains a certain level of competition between shareholders for access to the levers of corporate control.

The formation of a motivational mechanism for corporate cooperation, the components of which are the system of motivating the $\mathrm{CR}$ participants, management control system, system for evaluating the performance of the jointstock company, is one of the most important stages in the formation of the development strategy of the joint-stock company. The distribution of the corporation's profit, in its turn, becomes a source of satisfaction for the interests of a wide range of participants in $\mathrm{CR}$, that is, on the one hand, it is the main stimulus and driving force for the formation and development of a corporate organization, and on the other, it can lead to sharp contradictions or even corporate conflicts.

Receiving remuneration from participation in $\mathrm{CR}$ is a powerful motive and an effective incentive for the activation of corporate cooperation, which provides a close and inextricable link between the CR participants and the corporate organization created in the course of joint activities of the participants

For the personnel, financial incentives (pay) are the main motive of labor activity and a monetary measure of the value of the contribution, employees contribute to the activities of the corporation. Material motivation for the employees of the joint-stock company is also associated with the pleasure of a wider range of needs, the meaning of which is the pursuit of abundance, a certain level of well-being, high material standards of life, etc. Expanding the capacity of staff representatives to increase welfare, in turn, the need to increase the labor contribution to corporate cooperation, and, consequently, improving the performance of the company.

The availability of JSC professional management, responsible to the whole shareholders, is one of the most important advantages of the joint-stock form of business organization. However, the complexity of the relationship between shareholders and top managers is the reason for the spread of compliance with a variety of forms of long-term incentives for officials of joint-stock companies.

A necessary condition for creation and development of effective ways to harmonize the interests of shareholders and top managers is the formation of appropriate methodological and organizational and economic support for assessing the quality of corporate governance of the joint-stock company, which would allow an accurate and adequate definition of efficiency level of the top management of the corporation entrusted to it.

Achieving the goals, implementing the corporate development strategy of the joint-stock company directly depends on the influence of many external and internal factors. The emergence of new tasks, opportunities and constraints that accompany the development process requires adequate changes in the organization of production, restructuring of management and coordination mechanisms, changes in priorities and methods of planned activities. Thus, the course of the process of intra-organizational development is not chaotic and unpredictable, but is subject to the action of a complex of social, economic, organizational laws. In case of successful reform of the internal environment, the enterprise continues to grow at the current one or moves on to the next phase of evolutionary development. If internal changes are not consistent with the scale and complexity of the problems that arise, the joint-stock company may stop at the achieved level without showing further tendencies to growth or even fall into the crisis zone.

Specific means of solving the complex problem of choosing forms and methods of organizational support for sustainable development is the transformation of the composition and structure of elements of the internal environment of the joint-stock company, the forms and methods of coordinating their work in the course of joint activities, and changing internal regulations, norms and rules. Thus, the effectiveness of the implementation of the chosen development strategy is largely determined by the opportunities for accelerating the implementation of reforms, the flexible adaptation of goals, the value system and organizational culture to changes in the operating environment of the JSC, is complicated by the organizational resistance to innovation and the rising costs of overcoming it.

Organizational resistance is the JSC reaction as a social system to the action associated with the transformation of the conditions of its functioning (a kind of feedback that occurs in the development process). The sources of organizational resistance to change can be external forces (first of all, cooperation partners, suppliers, consumers, etc.), and JSC staff (internal resistance to change). Internal organizational resistance can be personal (determined by the disagreement of individual personalities with changes), or collective nature (determined by the differences between the chosen development strategy and the existing organizational culture, management structure, distribution of powers and responsibilities). Thus, the internal organizational resistance to changes, depending on the reasons for the non-acceptance by the staff of individual provisions or the chosen development strategy as a whole, may have different strength, direction and intensity.

In particular, resistance can manifest itself in the form of passive (latent) rejection of transformations, conducted or active (open) resistance to change. It should be borne in mind that the implicit form of passive resistance, which occurs for a relatively long time, is quite capable of causing much greater damage to the implementation of strategic plans and the achievement of the goals set by the JSC than active opposition.

The change in the strength and direction of the organizational resistance can also occur as the reforms deepen, during which the contradictions between the existing organizational culture and the management structure become more acute. A prerequisite for mitigating such contradictions and preventing exacerbation of intra-organizational conflicts is the timely identification of the reasons for resistance and the formation of a comprehensive set of measures to adapt personnel to the changes, flexible motivation and encourage employees to participate in the implementation of the JSC development strategy.

In the process of developing such program, it is necessary to take into account the need for an optimal combination of economic (providing for the concentration of material incentives and the will of employees to solve established tasks due to changes in the economic situation around the management object) and administrative-directive (direct submission to the will of workers to focus on Achievement 
of established management tasks) methods of resisting resistance. The implementation of the program of intraorganizational socio-cultural changes that ensure implementation of the JSC's development strategy should first of all be aimed at overcoming the antagonism between the management and ordinary employees, supporters and opponents of the transformations carried out with respect to the goals of strategic changes, which will ensure the conformity of the structural structure and features of the internal corporate mechanism management of the joint-stock company to the external conditions of the institutional corporate environment in their relations, the formation of which occurs only in the course of market reforms.

\section{SWOT analysis of research results}

Strengths. The strength of research is development of methodological support, which can be used by joint-stock companies to improve the organization of corporate relations, preventing the emergence of corporate conflicts, the development of a corporate development strategy.

Weaknesses. The weak side is that for the insider corporate governance system that emerged in Ukraine in the post-privatization period, the information base for evaluating the structural organization of corporate relations in joint-stock companies is limited for the low level of interest of the owners of the insider corporate controller in ensuring openness of the JSC management.

Opportunities. Opportunities for further research are development of recommendations for the protection and presentation of the interests of insiders and outsiders involved in the functioning of the corporation in order to ensure the fuller use of the advantages of the corporate form of business organization related to the disclosure of the potential of corporate development on the basis of deepening the productive cooperation of the CR participants.

Threats. Threats to the results of the conducted research are the existing low level of interest of the holders of insider shareholders in the formation of a balanced system of corporate control distribution.

\section{Conclusions}

1. A methodical approach to assessment of the structural organization of corporate relations in a joint-stock company is developed, which ensures the complexity of assessments of possible variants of corporate control distribution in JSCs, taking into account the existing division of powers between governance bodies in the management of a joint-stock company.

2. Based on the systematization of factors (concentration of ownership of corporate rights, influence of higher authorities, representation of shareholders, completeness of normative regulation, informational and external openness of JSC), the distribution and implementation of corporate control have been suggested recommendations regarding the integral assessment the corporate governance quality in a joint stock company.

3 . It is proved that the complexity of corporate relations that arise in a joint-stock company between its owners and hired senior management (SM) is primarily due to the feature of the functions performed by the SM members of the corporation and the specificity of their contribution to corporate development management. The choice of forms of coordination of the interests of the participants in such relationships (solving the problem of regulating relations «principal-agent») requires taking into account the structural organization of corporate relations, which affect the satisfaction of aspirations of shareholders and SM of the corporation.

\section{References}

1. Gracheva, N. Analysis in corporate governance [Text] / N. Gracheva // Economic Annals-XXI. - 2016. - Vol. 157, No. 3-4 (1). P. 85-87. doi:10.21003/ea.v157-0026

2. Krivtsun, L. A. Korporatsii na fondovomu rynku Ukrainy [Text]: Monograph / L. A. Krivtsun. - Kharkiv: NTU «KhPI», 2003. $432 \mathrm{p}$.

3. Shaw, J. C. Corporate Governance and Risk: A Systems Approach [Text] / J. C. Shaw. - Wiley, 2003. - 212 p.

4. Smith, R. C. Governing the Modern Corporation: Capital Markets, Corporate Control, and Economic Performance [Text] / R. C. Smith, I. Walter. - Oxford University Press, 2006. 336 p. doi:10.1093/0195171675.001.0001

5. Hummer, M. Beyond Reengineering. How the Process-Centered Organization is Changing Our Work and Our Lives [Text] / M. Hummer. - HarperBusiness, 1997. - 304 p.

6. Young, O. R. Limits to Privatization: How to Avoid Too Much of a Good Thing: A Report to the Club of Rome [Text] / ed. by O. R. Young, E. U. von Weizsacker, M. Beishem, M. Finger. Taylor\&Francis, 2005. - 256 p. doi:10.4324/9781849771832

7. Dmytrychenko, L. I. Korporatyvni vidnosyny: metodolohiia doslidzhennia ta mekhanizmy funktsionuvannia [Text]: Monograph / L. I. Dmytrychenko, A. M. Khimchenko, M. O. Kuzheliev, M. P. Kalynychenko. - Donetsk: Skhidnyi vydavnychyi dim, 2012. - $158 \mathrm{p}$.

8. Bolten, S. E. Stock Market Cycles: A Practical Explanation [Text] / S. E. Bolten. - Praeger, 2000. - 184 p.

9. Grinblatt, M. Financial Markets\&Corporate Strategy [Text] / M. Grinblatt, S. Titman. - Ed. 2. - McGraw-Hill Publishing Co., 2001. - 912 p.

10. Gritans, Ya. Korporativnye otnosheniia: pravovoe regulirovanie organizatsionnyh form [Text] / Ya. Gritans. - Moscow: Volters Kluver, 2005. - 160 p.

11. Kibenko, O. R. Yevropeiske korporatyvne pravo na etapi fundamentalnoi reformy: perspektyvy vykorystannia yevropeiskoho zakonodavchoho dosvidu u pravovomu poli Ukrainy [Text]: Monograph / O. R. Kibenko. - Kharkiv: Straid, 2005. - 432 p.

12. Van Frederikslust, R. A. I. Corporate Governance and Corporate Finance: A European Perspective [Text] / ed. by R. A. I. van Frederikslust, J. S. Ang, P. S. Sudarsanam. Routledge, 2007. - 784 p. doi:10.4324/9780203940136

\section{ОЦЕНКА СТРУКТУРНОЙ ОРГАНИЗАЦИИ КОРПОРАТИВНЫХ ОТНОШЕНИЙ ЛРИ ФОРМИРОВАНИИ СТРАТЕГИИ РАЗВИТИЯ КОРПОРАЦИИ}

Рассмотрены организационные аспекты корпоративных отношений в акционерном обществе при формировании стратегии развития корпорации. Предложен методический подход к оценке структурной организации корпоративных отношений и распределения корпоративного контроля в акционерном обществе. Рассмотрено мотивационное обеспечение преодоления сопротивления организационным изменениям в процессе реализации стратегии развития акционерного общества.

Ключевые слова: корпоративные отношения, акционерное общество, стратегия развития, корпоративный контроль, корпоративное управление.

Popov Oleksandr, Doctor of Economic Sciences, Professor, Head of the Department of Political Economy, Simon Kuznets Kharkiv National University of Economics, Ukraine, e-mail: Oleksandr.Popov@m.hneu.edu.ua, ORCID: http://orcid.org/0000-0003-0550-7890

Serdyukov Konstantin, PhD, Associate Professor, Department of Economics and Business Property Valuation, Simon Kuznets Kharkiv National University of Economics, Ukraine, e-mail: serdukov.kg@gmail.com, ORCID: http://orcid.org/0000-0001-8294-3317 